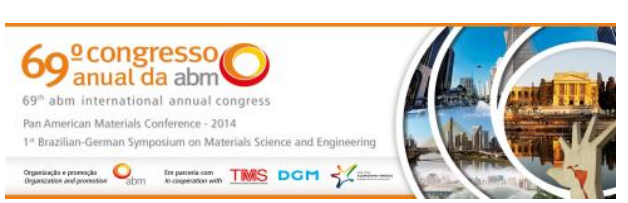

Theme: Nanotecnology

\title{
PHOTOCATALYTIC ACTIVITY OF ZINC OXIDE NANOSTRUCTURED SYNTHESIZED BY COMBUSTION IN SOLUTION*
}

\author{
Waleska Campos Guaglianoni \\ Ana Paula Garcia ${ }^{2}$ \\ Jaqueline Oliveira Barnasque ${ }^{3}$ \\ Juliano Schorne Pinto ${ }^{4}$ \\ Tania Maria Basegio ${ }^{5}$ \\ Carlos Pérez Bergmann ${ }^{6}$
}

\begin{abstract}
With the growth of nanoscience and nanotechnology, the synthesis of nanostructured oxides has received a special attention. Metal oxides are widely used in the manufacture of microelectronic circuits, piezoelectric devices, fuel cells, catalysts, filters and bactericides systems. These metal oxides represent a large class of semiconductor materials suitable for photocatalytic processes. In recent years, new materials of this class such as $\mathrm{TiO} 2$ and $\mathrm{ZnO}$ have been developed due to their photo-catalytic abilities to degrade various environmental pollutants. This work aimed to evaluate the photocatalytic activity of zinc oxide previously synthesized by combustion synthesis in solution using citric acid as fuel and different reasons fuel/oxidant. After synthesis, the powders were subjected to heat treatments at different temperatures and photo-catalysis. The photocatalytic activity was evaluated by the degradation of a solution of methyl orange in a photochemical reactor of UV illumination, after which the transmittance of the samples measured with the assistance of a spectrophotometer. To analyze the results, a commercial zinc oxide was used as standard. The products of combustion synthesis in solution showed that photocatalytic activity varied according to the ratio fuel/oxidant and as a function of heat treatment. The results showed a higher photocatalytic activity for the products obtained with disabilities fuel in the reaction and heat treated.
\end{abstract}

Keywords: Photocatalysis; Zinc oxide; Nanostructured; Combustion in solution.

1 Materials Engineers, Masters Student in Mining Engineering, Metallurgical and Materials, PPGEM/Escola de Engenharia, Universidade Federal do Rio Grande do Sul (UFRGS), Porto Alegre, RS, Brasil.

2 Chemical, Masters in Mining Engineering, Metallurgical and Materials, PPGEM, Escola de Engenharia, UFRGS, Porto Alegre, RS, Brasil.

3 Materials Engineering Student, Bolsista de Iniciação Científica, PPGEM, Escola de Engenharia, UFRGS, Porto Alegre, RS, Brasil.

4 Materials Engineering Student, Bolsista de Iniciação Científica, PPGEM, Escola de Engenharia, UFRGS, Porto Alegre, RS, Brasil.

5 Chemical, Doctor in Mining Engineering, Metallurgical and Materials, Bolsista de Pós-doutorado Júnior do CNPq, PPGEM, Escola de Engenharia, UFRGS, Porto Alegre, RS, Brasil.

6 Metallurgical Engineers, Doctor in Engineering, Bolsista de Produtividade em Pesquisa do CNPq Nível 1A, PPGEM, Escola de Engenharia, UFRGS, Porto Alegre, RS, Brasil.

\footnotetext{
* Technical contribution to the $69^{\text {th }}$ ABM International Annual Congress and to the ENEMET, July $21^{\text {st }}-25^{\text {th }}$, 2014, São Paulo, SP, Brazil.
} 


\section{INTRODUCTION}

Zinc oxide $(\mathrm{ZnO})$ is a semiconductor non-stoichiometric $\mathrm{n}$-type due to the presence of native defects that may be generated by vacancy formation of oxygen atoms [1]. It has high binding energy $(60 \mathrm{meV})$, "bandgap" of about $3.37 \mathrm{eV}$, high optical and luminescent activity. In addition to being an excellent material for the field of semiconductors, zinc oxide degrades organic dyes through photo-catalysis. ZnO can be obtained by various procedural routes. The technique employed in this work is the combustion synthesis in solution (CSS) [2]. This method has the advantages of inexpensive raw materials, a relatively simple preparation process, and a fine resulting powder with high homogeneity.

Photo-catalysis is an advanced oxidation process widely used in water treatment and industrial effluents. In this process, the metal oxide semiconductor absorbs radiant energy (visible or ultraviolet) and makes a pair of electron/hole $\left(e-, h_{+}\right)$in the conduction and valence bands [3-6]. The combination of water molecules with gaps can generate hydroxyl radicals $(\mathrm{OH} \bullet$ ) highly reactive that will act on the surface of the contaminant and promote degradation.

The aim of this work is to evaluate the photocatalytic activity of nanostructured $\mathrm{ZnO}$, which was obtained by CSS, in methyl orange compound degradation, a dye widely used in textile industries.

\section{MATERIAL AND METHODS}

Figure 1 shows the flowchart of the experimental procedure.

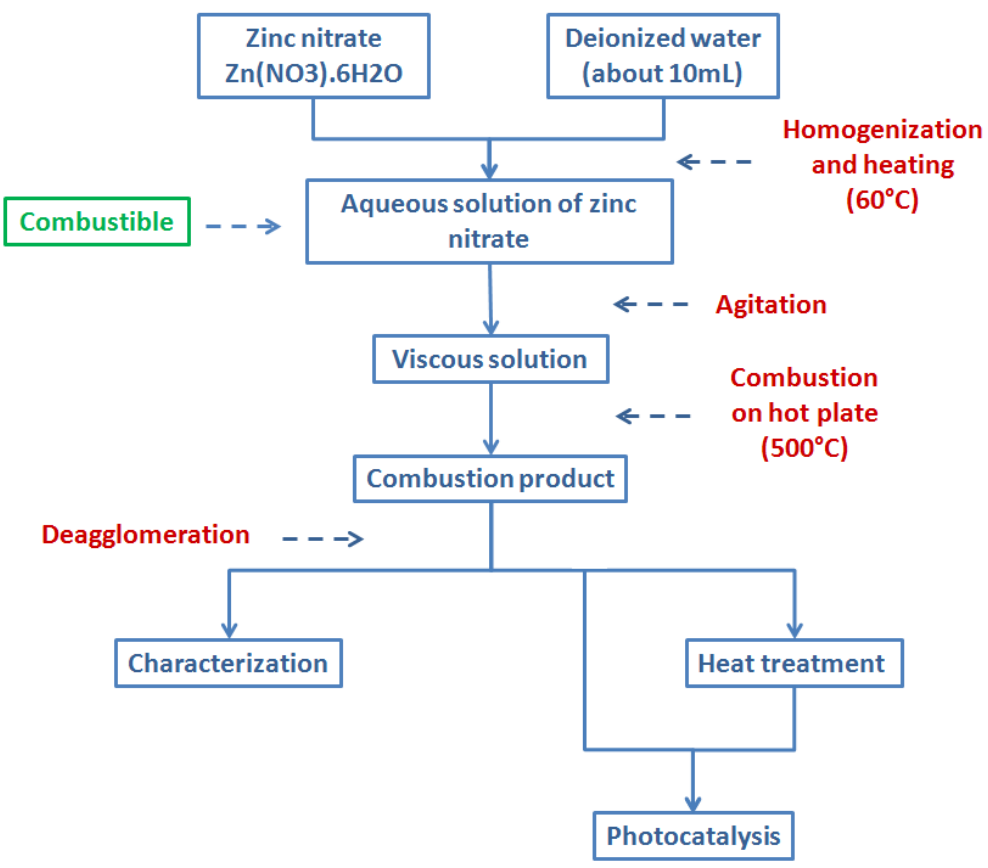

Figure 1. Flowchart of the experimental procedure adopted.

\subsection{Combustion Synthesis of ZnO in Solution}

The precursor solutions were prepared using zinc nitrate hexahydrate and citric acid monohydrate produced by Vetec Química Ltda. Additional information about the reagents is listed in Table 1.

\footnotetext{
* Technical contribution to the $69^{\text {th }}$ ABM International Annual Congress and to the ENEMET, July $21^{\text {st }}-25^{\text {th }}, 2014$, São Paulo, SP, Brazil.
} 
Table 1. Characteristics of the reagents involved in CSS of $\mathrm{ZnO}$

\begin{tabular}{cccc}
\hline Chemical reagent & Formula & Purity (\%) & Reaction function \\
\hline Zinc nitrate hexahydrate & $\mathrm{Zn}\left(\mathrm{NO}_{3}\right)_{2} \cdot 6 \mathrm{H}_{2} \mathrm{O}$ & 98 & Oxidant \\
\hline Citric acid monohydrate & $\mathrm{C}_{6} \mathrm{H}_{8} \mathrm{O}_{7} . \mathrm{H}_{2} \mathrm{O}$ & 99,5 & Fuel \\
\hline
\end{tabular}

The fuel/oxidant ratios were defined from the thermodynamic modeling based on the chemistry of propellants and explosives [7]. Precursor solutions were prepared with different quantities of chemical reagents according to the calculated stoichiometric equation. The quantities of reagents used in reactions were 50 and $25 \%$ excess in fuel, stoichiometric ratio between fuel and zinc nitrate and 50 and $25 \%$ deficient in fuel.

Firstly, the metal nitrate was dissolved with deionized water (approximately $10 \mathrm{~mL}$ ). Secondly, the solution was heated at $60^{\circ} \mathrm{C}$ under constant magnetic stirring. After 10 minutes, fuel was added. Then, the solution was agitated for 10 minutes. The electric plate was heated up to $500^{\circ} \mathrm{C}$ to accomplish combustion reactions. Due to the output of reactive gases, the procedure was performed under forced exhaustion. The reaction products of synthesis were comminuted for 5 minutes and sieved through 325 mesh (opening of $44 \mu \mathrm{m}$ ).

\subsection{Characterization of the Powders Obtained}

Crystalline phases and crystallite sizes were determined using X-ray powder diffraction (Phillips diffractometer, X'Pert MPD model). The diffractometer has a graphite monochromator, $\mathrm{Cu}-\mathrm{Ka}$ radiation $(\lambda=1,5406)$, and a fixed anode operated at $40 \mathrm{kV}$ and $40 \mathrm{~mA}$.

Table 2 shows the selected parameters for the phase analysis and determination of crystallite size.

Table 2. Parameters for $\mathrm{XRD}$ analysis.

\begin{tabular}{ccc}
\hline Parameter & Phase analysis & Crystallite size \\
\hline$\Delta 2 \theta$ & $5^{\circ}-75^{\circ}$ & $41.5^{\circ}-51.5^{\circ}$ \\
Step & 0.05 & 0.02 \\
Time per step (s) & 1 & 4 \\
Cracks & $1 / 4$ & $1 / 4$ \\
\hline
\end{tabular}

The crystallite size was calculated with WinFit software (version 1.2). The experimental peaks are fit using asymmetric Pearson VII functions. They can be corrected for instrumental broadening and decomposed into two components: Gaussian and Lorentzian. Gaussian contribution characterizes the effect on crystallites size and Lorentzian contribution characterizes the effect of microstrain on the breadth of diffraction peaks. Therefore, determining Pearson VII specific functions for each diffraction maximum allows us to calculate the average size of crystallites [8].

\subsection{Heat Treatment}

The heat treatment of the reaction products consisted in heating the synthesized powders in electric muffle furnace at temperatures $600^{\circ} \mathrm{C}$ and $800^{\circ} \mathrm{C}$, with a heating rate of $10^{\circ} \mathrm{C} / \mathrm{min}$ and one hour of dwell time.

\subsection{Photocatalytic Activity}

\footnotetext{
* Technical contribution to the $69^{\text {th }} A B M$ International Annual Congress and to the ENEMET, July $21^{\text {st }}-25^{\text {th }}, 2014$, São Paulo, SP, Brazil.
} 


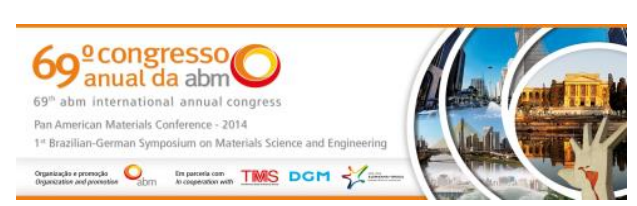

The equipment used in the process was a light irradiation device UV-A, consisting of twelve UV-A lamps (Xelux F8T5/BLB - black light) of 8W, two half-cylinders with reflective internal surface, stir plate, a system for supply of compressed air and a thermostatic bath (Figure $2 \mathrm{a}$ ). The reactor (Figure $2 \mathrm{~b}$ ) pyrex glass has an orifice sealed by a silicone septum to remove the samples, an external jacket for water circulation, and an exit orifice with a porous membrane at the end.

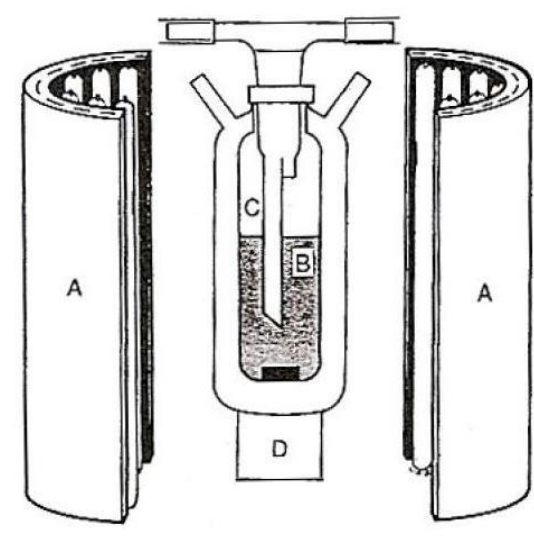

(a)

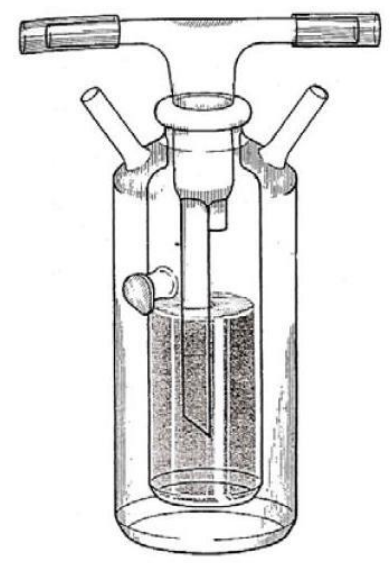

(b)

Figure 2. (a) UVA radiation system: A-lamp support assembly, B-bottle reactor, C-air bubbler, D magnetic stirrer; (b) details of the bottle reactor [9].

It was added $50 \mathrm{mg}$ of $\mathrm{ZnO}$ nanostructure in $125 \mathrm{ml}$ of a $20 \mathrm{ppm}$ solution of methyl orange dye (Sigma-Aldrich). This mixture was homogenized with ultrasound in a dark chamber for 15 minutes for better dispersion of the material and initial adsorption of the dye on the surface of the catalyst. A sample of approximately $4 \mathrm{~mL}$ was removed immediately after the homogenization stage. The content was then transferred to a pyrex reactor and its color disappearance was monitored by spectrophotometric measurements at a wavelength of $450 \mathrm{~nm}$. Samples without heat treatment and those calcined at $600^{\circ} \mathrm{C}$ were obtained at 5 minutes intervals. The calcined samples at $800^{\circ} \mathrm{C}$ were obtained at 30 minutes intervals. For transmittance measurements, the samples collected were placed in buckets of polymethylmethacrylate (PMMA). The methyl orange degradation by commercial zinc oxide (Synth) was also investigated.

\section{RESULTS AND DISCUSSION}

\subsection{Characterization of the Powders Obtained by CSS}

The X-ray diffraction patterns of powders obtained are shown in Figure 3. For all samples, it was observed the characteristic peaks of zinc oxide (zincite) for values of $2 \theta 31.85^{\circ}, 34.55^{\circ}$ and $36.36^{\circ}$, recognized by Miller indices (100), (002) and (101) respectively [10]. All samples showed a sufficient degree of crystallinity. However, the $\mathrm{ZnO}$ powders obtained with lower amount of citric acid (poor compositions) showed the most intense peaks on the X-ray diffraction, suggesting that samples are more crystalline.

\footnotetext{
* Technical contribution to the $69^{\text {th }} A B M$ International Annual Congress and to the ENEMET, July $21^{\text {st }}-25^{\text {th }}$, 2014, São Paulo, SP, Brazil.
} 

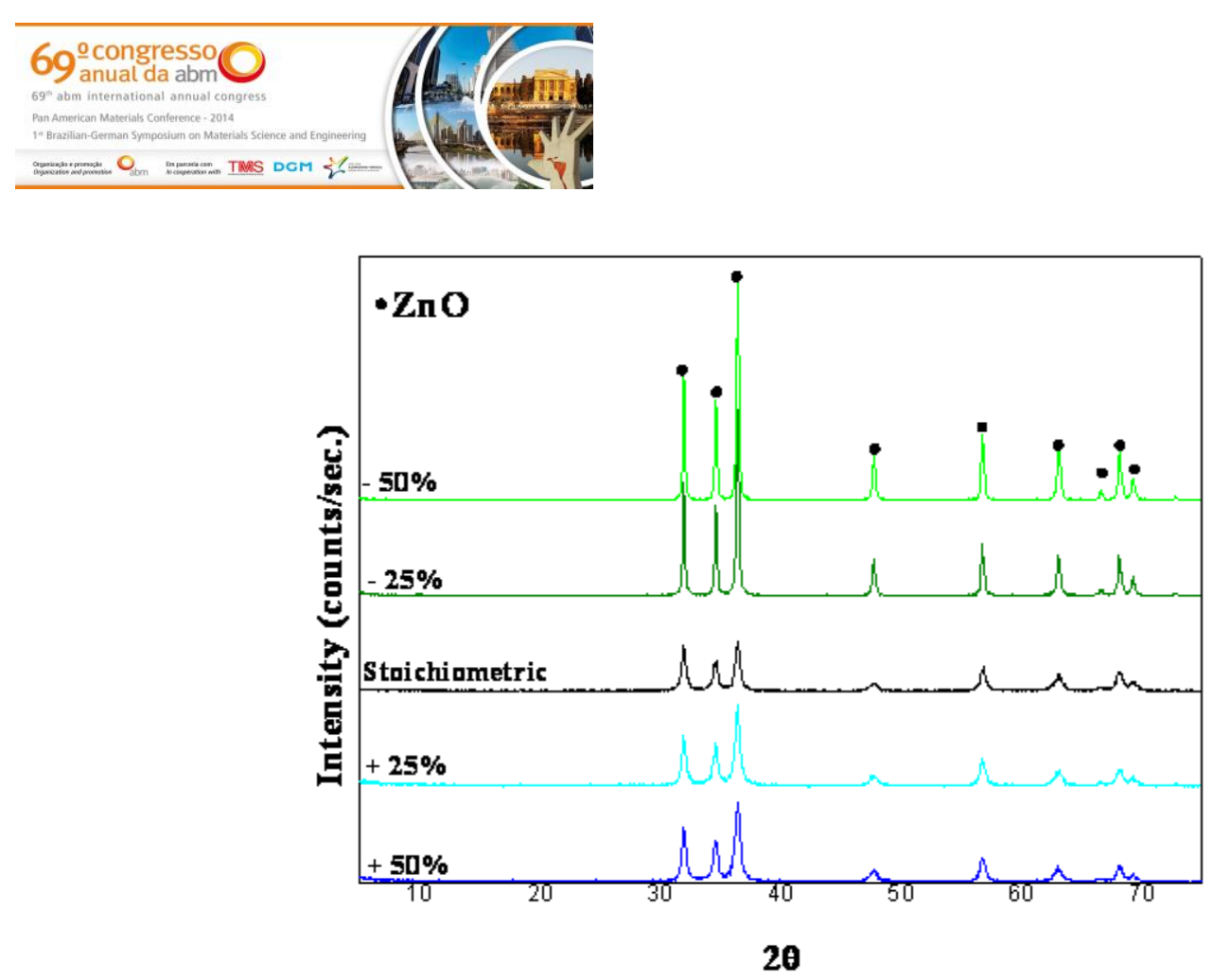

Figure 3. X-ray diffraction patterns of the powders obteined.

The products obtained in this work are nanocrystallites with the sizes ranging between 9.2 and $41.6 \mathrm{~nm}$. According to the results (Table 3), the larger crystalline sizes are correlated with poor compositions in citric acid.

Table 3. Crystallite size of the products of CSS of $\mathrm{ZnO}$

\begin{tabular}{cc}
\hline Fuel amount (\%) & $\begin{array}{c}\text { Crystallite size } \\
(\mathrm{nm})\end{array}$ \\
\hline+50 & 9.2 \\
+25 & 28.1 \\
Stoichiometric & 10.7 \\
-50 & 30.7 \\
-25 & 41.6 \\
\hline
\end{tabular}

The results differ partly from those reported in the literature [11-13]. According to Toniolo [11], should be observed crystal growth due to the increase of the fuel/oxidant ratio. The authors believe that the largest crystallite size of the samples deficient in fuel was caused by the less quantity of gas formed during the combustion synthesis. As the particles tend to agglomerate when there is a reduced amount of gas, the crystallite size increases.

\subsection{Photocatalytic Activity}

Figure 4 shows the variation of the relative concentration $(\mathrm{C} / \mathrm{Co})$ of methyl orange dye as a function of reaction time using photo-catalysts $\mathrm{ZnO}$ powders obtained by CSS and comercial $\mathrm{ZnO}$. It was observed that the samples deficient in fuel, which have higher crystallinity, showed the best photocatalytic performance. At the same time, the samples with excess in fuel and stoichiometric did not show significant degradation. In these samples, it is suggested that the presence of organic matter in excess interfered in the degradation of methyl orange.

\footnotetext{
* Technical contribution to the $69^{\text {th }}$ ABM International Annual Congress and to the ENEMET, July $21^{\text {st }}-25^{\text {th }}$, 2014, São Paulo, SP, Brazil.
} 

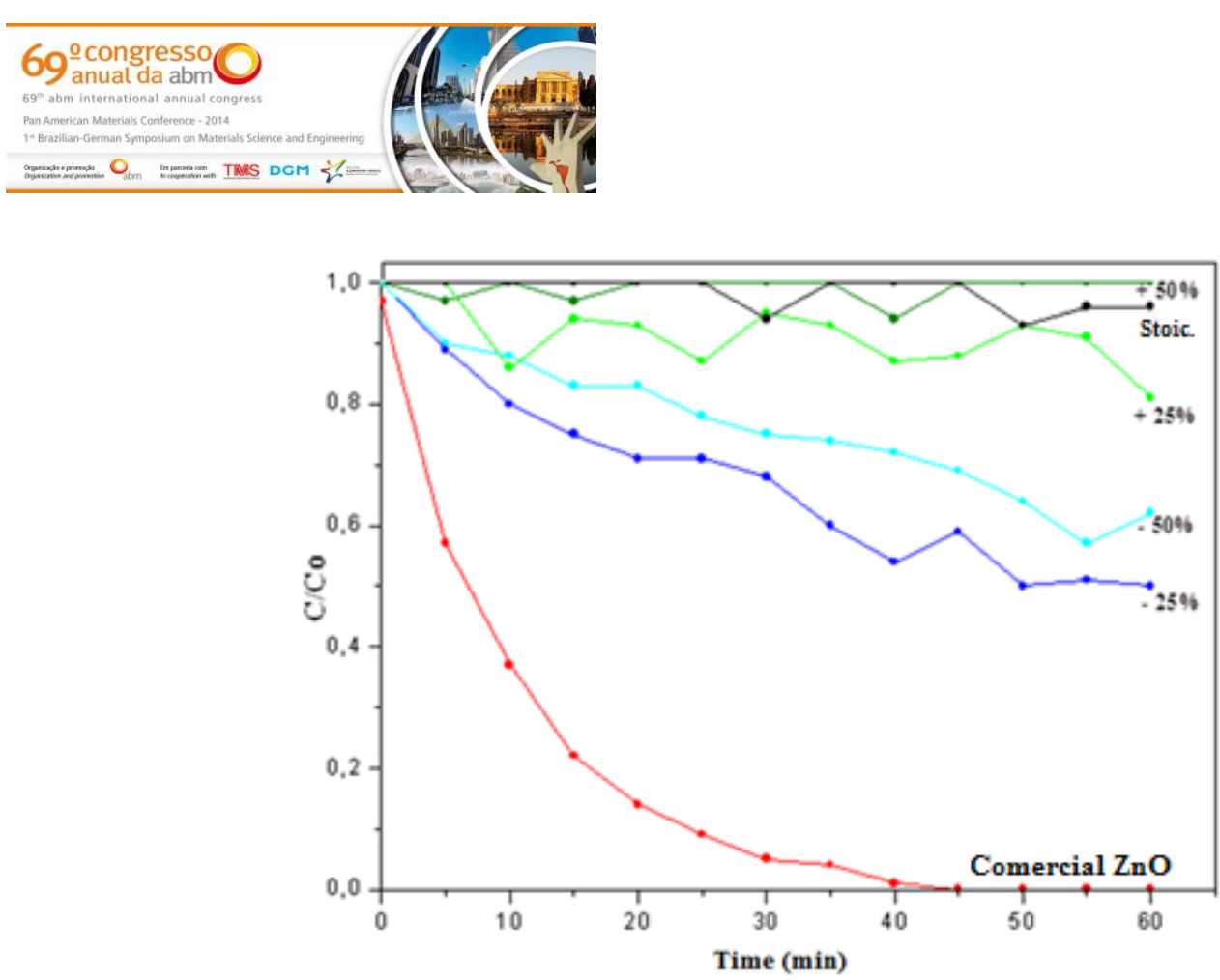

Figure 4. Variation of the relative concentration $(\mathrm{C} / \mathrm{Co})$ of the dye as a function of reaction time using $\mathrm{ZnO}$ powders obtained via CSS and comercial $\mathrm{ZnO}$.

For the samples heat treated at $600^{\circ} \mathrm{C}$, the variation of the relative concentration $(\mathrm{C} / \mathrm{Co})$ of methyl orange dye as a function of reaction time can be observed in Figure 5. The degradation efficiency of the samples rich in fuel increases with heat treatment. This enhancement in photocatalytic activity can be explained by the elimination of organic matter and the probable increase in the crystallinity of the material with the thermal treatment.

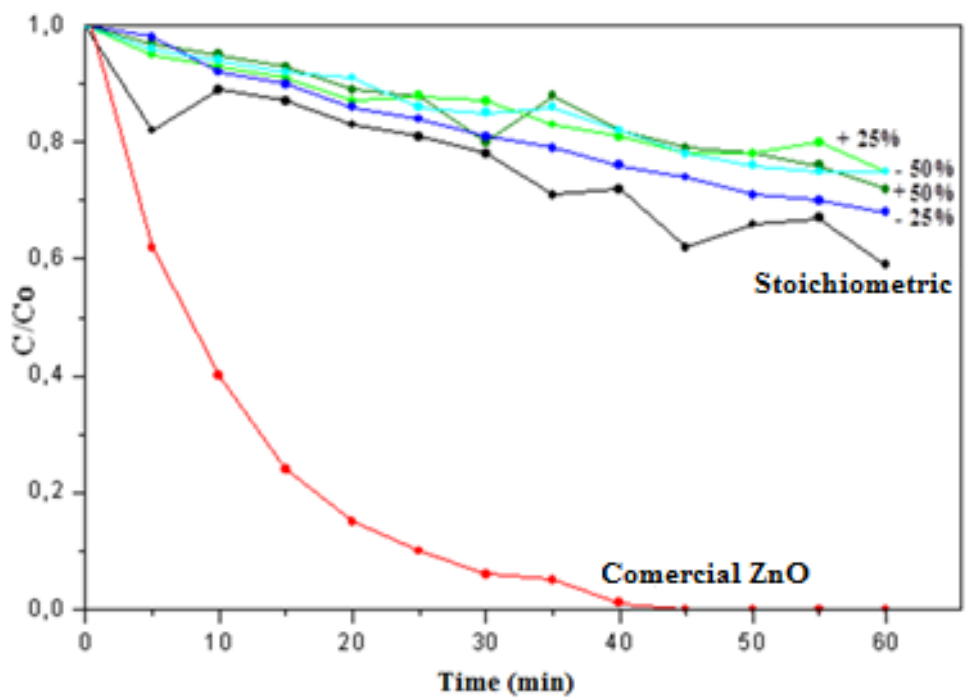

Figura 5. Variation of the relative dye concentration $(\mathrm{C} / \mathrm{Co})$ as function of time for the calcined powders at $600^{\circ} \mathrm{C}$ and the comercial $\mathrm{ZnO}$.

Curves of $\mathrm{C} / \mathrm{C}_{0}$ versus irradiation time for the calcined powders at $800^{\circ} \mathrm{C}$ are shown in Figure 6. The stoichiometric sample presented higher catalytic activity than other synthesized products investigated. 


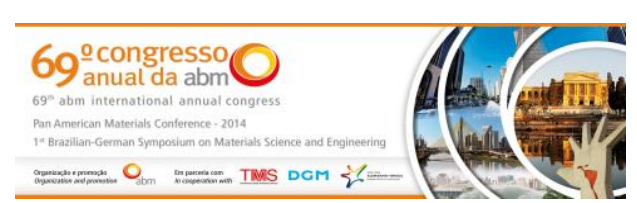

2 Souza VC. Varistores de ZnO obtidos por reação de combustão. São Paulo: Blucher Acadêmico; 2008.

3 Nogueira RFP, Jardim WF. A fotocatálise heterogênea e sua aplicação ambiental. Química Nova, 1998; 21: 69-72.

4 Kunz A, Peralta-Zamora P, Moraes Sg, Dúran N. Novas tendências no tratamento de efluentes têxteis. Química Nova, 2002; 25: 78-82.

5 Magalhães F. Síntese e caracterização de óxidos de ferro e compósitos para aplicação no tratamento redox de efluentes aquosos. [Doctor thesis]. Belo Horizonte: Universidade Federal de Minas Gerais; 2008.

6 Carvalho Ktg. Síntese e modificação de óxidos de nióbio para o uso como catalisadores em reações de oxidação: Estudos por cálculos teóricos e evidências experimentais. [Master in Agrochemical] Lavras: Universidade Federal de Lavras; 2009.

7 Jain Sr. Energetics of Propellants, Fuels and Explosives. Propellants, Explosives, Pyrotechnics, 1987; 12: 188-195.

8 Onisei S, Badilita V, Stoiciu F, Velea T, Predica V, Lupu C, et al. Mechanochemical Activation of Copper Concentrate and the Effect on Oxidation of Metal Sulphides. Revista de Chimie, 2012; 63, 591-597.

9 Alves Ak. Obtenção de micro e nanofibras de $\mathrm{TiO}_{2}$ por electrospinning: caracterização de propriedades e atividade fotocatalítica. [Doctor thesis]. Porto Alegre: Universidade Federal do Rio Grande Do Sul; 2008.

10 Sawada H, Wang R, Sleight Aw. J. Solid State Chem., 1996; 122-148.

11 Toniolo Jc. Síntese de pós de alumina nanocristalina por combustão em solução. [Master in Enginnering] Porto Alegre: Universidade Federal do Rio Grande Do Sul; 2004.

12 Toniolo Jc. Influência da razão combustível - oxidante nas características de óxidos nanoestruturados sintetizados por combustão em solução. [Doctor thesis]. Porto Alegre: Universidade Federal do Rio Grande Do Sul; 2009.

13 Dalt $\mathrm{S}$. Síntese por combustão em solução de $\mathrm{MgF}_{\mathrm{e} 2 \mathrm{O} 4}$ nanoestruturado utilizando anidrido maleico como combustível e sua caracterização estrutural e maganética. [Master in Enginnering]. Porto Alegre: Universidade Federal do Rio Grande Do Sul; 2008.

* Technical contribution to the $69^{\text {th }} A B M$ International Annual Congress and to the ENEMET, July $21^{\text {st }}-25^{\text {th }}$, 2014, São Paulo, SP, Brazil. 